\title{
Increase in mitotic recombination in diploid cells of Aspergillus nidulans in response to ethidium bromide
}

\author{
Tânia C.A. Becker, Simone J.R. Chiuchetta, Francielle Baptista and Marialba A.A. de Castro-Prado \\ Universidade Estadual de Maringá, Departamento de Genética e Biologia Celular Maringá, PR, Brazil.
}

\begin{abstract}
Ethidium bromide (EB) is an intercalating inhibitor of topoisomerase II and its activities are related to chemotherapeutic drugs used in anti-cancer treatments. EB promotes several genotoxic effects in exposed cells by stabilising the DNA-enzyme complex. The recombinagenic potential of EB was evaluated in our in vivo study by the loss of heterozygosity of nutritional markers in diploid Aspergillus nidulans cells through Homozygotization Index (HI). A DNA repair mutation, uvsZ and a chromosome duplication DP (II-I) were introduced in the genome of tested cells to obtain a sensitive system for the recombinagenesis detection. EB-treated diploid cells had $\mathrm{HI}$ values significantly greater than the control at both concentrations $\left(4.0 \times 10^{-3}\right.$ and $\left.5.0 \times 10^{-3} \mu \mathrm{M}\right)$. Results indicate that the intercalating agent is potentially capable of inducing mitotic crossing-over in diploid $A$. nidulans cells.
\end{abstract}

Key words: antineoplastic drug, Aspergillus nidulans, ethidium bromide, intercalating agent, mitotic crossing over.

Received: February 24, 2003; Accepted: May 29, 2003.

\section{Introduction}

DNA topoisomerase II (topo II) is a ubiquitous enzyme that regulates DNA topologic interconversion during replication, transcription and genetic recombination decreasing torsional stress in DNA by introducing transient protein-bridged DNA breaks in both DNA strands. Through this function, topo II plays an essential role in the maintenance of genetic material integrity (Mo and Beck, 1999; Godard et al., 2002). Several topo II inhibitors, such as doxorrubicin, etoposide and ellipticine, have been extensively used as chemotherapeutic agents in anti-cancer treatments. Rather than inhibiting the catalytic activity of the topo II enzyme, they act by increasing levels of topo II mediated DNA cleavage. This mechanism converts essential enzyme into a potent cellular toxin, inducing apopitosis, cell cycle arrest and genotoxicity (Nitiss and Beck, 1996; Attia et al., 2002). In fact, long-term adverse effects of this class of chemotherapic items, such as infertility and increased incidence of secondary malignancies, have been shown (Tiburi et al., 2002).

Much evidence has emphasised that somatic recombination preponderantly promotes genome instability associated with carcinogenesis (Tiburi et al., 2002; Laird and Jaenisch, 1996; Faruqi et al., 1994).

In fact, mitotic crossing-over is not only a factor associated with proto-oncogenes activation by favoring gene

Send correspondence to M.A.A. Castro-Prado. Avenida Colombo, 5790, 87020-900 Maringá, PR, Brazil. E-mai: maacprado@ uem.br. amplification and transpositions, but also causes neoplasies progression through loss of heterozygosity at tumorsuppressor loci. Heterozygous cells bearing a normal and a defective tumor-suppressor allele may lose the remaining wild-type allele by somatic chromosomal exchange at mitosis (Zimmermann et al., 1966; Ramel et al., 1996; Weinberg, 1991).

In current in vivo study, the potential of ethidium bromide (EB), an intercalating inhibitor of topo II in inducing somatic recombination, was evaluated through Homozygotization Index (HI) in diploid Aspergillus nidulans cells (Pires and Zucchi, 1994; Baptista and Castro-Prado, 1997, Chiuchetta and Castro-Prado, $2002 a$ and $b$ ). Loss of heterozygosity from nutritional markers was enhanced by the introduction of chromosome duplication DP (II-I) and $u v s Z$ DNA repair mutation in tested cells (Baptista and Castro-Prado, 2001). The filamentous fungus Aspergillus nidulans has an extensive genetic homology to higher eukaryotes, which makes it a suitable model organism for monitoring genetic toxicity when the effects of chemical and physical agents are studied (Busso et al., 2001).

\section{Materials and Methods}

\section{Strains}

The A. nidulans strains used are described in Table 1. The Z1 mutant is derived from master strain UT448 after treatment with N-methyl-N'-nitro-N-nitrosoguanidine (MNNG). The mutant bears Dp(II,I) duplication: a segment 
Table 1 - Genotype and origin of strains.

\begin{tabular}{lll}
\hline Strains & Genotype & Origin \\
\hline A757 & yA2, methA17, pyroA4 & FGSC \\
Z1 & $\begin{array}{l}\text { riboA1; pabaA124; biA1; uvsZ1; AcrA1; } \\
\text { wA2; Dp }(I I-I)\end{array}$ & Zucchi, 1990 \\
& & \\
\hline
\end{tabular}

Mutant alleles give the following phenotypes: ribo, paba, bi, meth, pyro, requirements for riboflavin, $p$-aminobenzoic acid, biotin, methionine and pyridoxine respectively; $y$ and $w$ : yellow and white conidial color, respectively; AcrA1, resistant to Acriflavine; Dp (II,I), duplicated segment from chromosome II, transposed to chromosome I. FGCS: Fungal Genetic Stock Center (University of Kansas Medical Center, Kansas U.S.A.).

from chromosome II duplicated and transposed to chromosome I, including the Acr, $w$ and meth + genes (Baptista and Castro-Prado, 2001; Castro-Prado and Zucchi, 1991).

\section{Culture Media}

Minimum Medium (MM) was Czapek - Dox with $1.0 \%(\mathrm{w} / \mathrm{v})$ glucose. Complete Medium (CM) has been previously described (Pontecorvo et al., 1953; Van de Vate and Jansen, 1978). Supplemented medium (SM) consisted of MM plus the nutriments required by each strain. Solid medium contained $1.5 \%$ agar. Incubation occurred at $37^{\circ} \mathrm{C}$.

\section{Methods}

The general methodology followed previous reports (Pontecorvo et al., 1953; Roper, 1952). The diploids were prepared by the method by Roper (Roper, 1952).

\section{Drug toxicity evaluation}

Ethidium bromide (InvitrogenCo) was added to CM to obtain final $4.0 \times 10^{-3}$ and $5.0 \times 10^{-3} \mu \mathrm{M}$ concentrations. Conidia of the Z1//A757 diploid strain were inoculated in plates containing $\mathrm{CM}$ (control) and $\mathrm{CM}+\mathrm{EB}$ (treatment). Ten plates were used for each dose and for control. Colony diameters were measured after 24, 48, 72 and $96 \mathrm{~h}$ incubation. Colony diameters, with and without the drug, were compared by Student's $t$ test.

\section{Evaluation of recombinagenic potential}

The Z1//A757 diploid strain conidia were inoculated in plates with $\mathrm{MM}+\mathrm{EB}$. Plates were incubated for 6 days at $37^{\circ} \mathrm{C}$. Treatment produced visible diploid sectors, identified by differentiated morphology of the original diploid. Sectors (D1-D4) were homozygous $(+/ /+)$ or heterozygous $(+/ /-$ or $-/ /+)$ diploid segregants. They were never recessive homozygous (-//-) since they do not grow in MM. Diploid sectors were haploidized spontaneously in $\mathrm{CM}$ and then purified in MM.

After haploidization the haploid mitotic segregants from diploid D1 to D3 were purified in CM. Only stable mitotic segregants were selected for the recombinagenic test and determination of the Homozygotization Indexes (HI) (Pires and Zucchi, 1994; Franzoni et al., 1997).

\section{Determination of the Homozygotization Indexes $(\mathrm{HI})$}

Nutritional markers of the haploid segregants will segregate in the proportion (a) 4+:4-, if the drug fails to induce recombinagenesis or (b) 4+: 2-, if drug induces crossing-over (Figure 1). Thus Homozygotization Indexes (HI), or the ratio between prototrophic segregants and auxotrophic segregants, equal to or over $2.0(4+/ 2-)$, show the recombinagenic effect of the compound under analysis (Figure 1) (Chiuchetta and Castro-Prado, 2002a and b). The HIs for markers from recessive homozygous diploids (-//-) cannot be calculated because they are not selected in MM. Results were compared by Yates correct Chi-Square test.

\section{Results}

Although the EB treatment of the Z1//A757 original diploid strain in $\mathrm{MM}$ does not allow the isolation of auxotrophic diploids (-//-), it is possible to obtain homozygous recessive diploids for conidia coloration markers $(y$ and $w$ ). The treatment of the Z1//A757 diploid strain with the intercalating agent allowed the isolation of prototrophic diploids with green $(y+/ / y)$, yellow $(y / / y)$ and white $(w / / w)$ conidia (Figure 2). Phenotypic analyses of the D2 (yellow) and D4 (white) diploids showed they were recombinant for centromere-paba and $w$-centromere intervals, respectively. Treatment also produced homozygous and heterozygous diploid segregants (D1-D3) for nutritional markers and they were selected for HI determination.

Solid cultures of the Z1//A757 diploid strain in CM + EB $\left(4.0 \times 10^{-3} \mu \mathrm{M}\right.$ or $\left.5.0 \times 10^{-3} \mu \mathrm{M}\right)$ exhibited reduction of the fungal growth after $48 \mathrm{~h}$ incubation. However, after 72 to $96 \mathrm{~h}$ the mycelial growth of the diploid strain in the presence of EB was normal, when compared to the control (growth of diploid Z1 // A757 in CM) (Figure 3).

The untreated Z1// A757 diploid strain exhibited increase in spontaneous mitotic exchange, and this result may be explained by the mitotic instability of the $\mathrm{Z} 1$ mutant. His $>2.0$ were in fact obtained for markers from chromosomes I and IV of the Z1 // A757 diploid strain (Table 2, control).

D1 diploid, obtained with $4.0 \times 10^{-3} \mu \mathrm{M} E B$, showed His $>2.0$ for the chromosome I markers. Two segregants
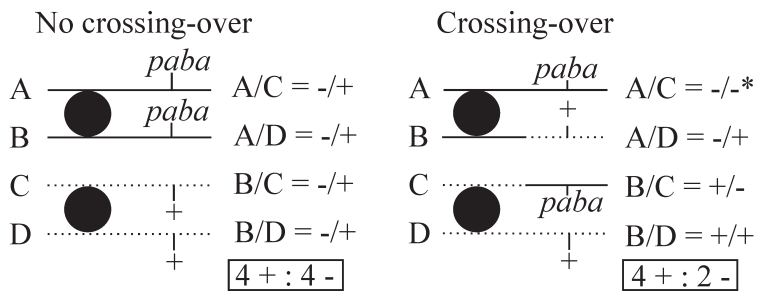

(*) Do not grow in MM

Figure 1 - Origin of heterozygous (+//- and -//+) and homozygous (+//+) diploids promoted by mitotic crossing-over between paba and the centromere. 

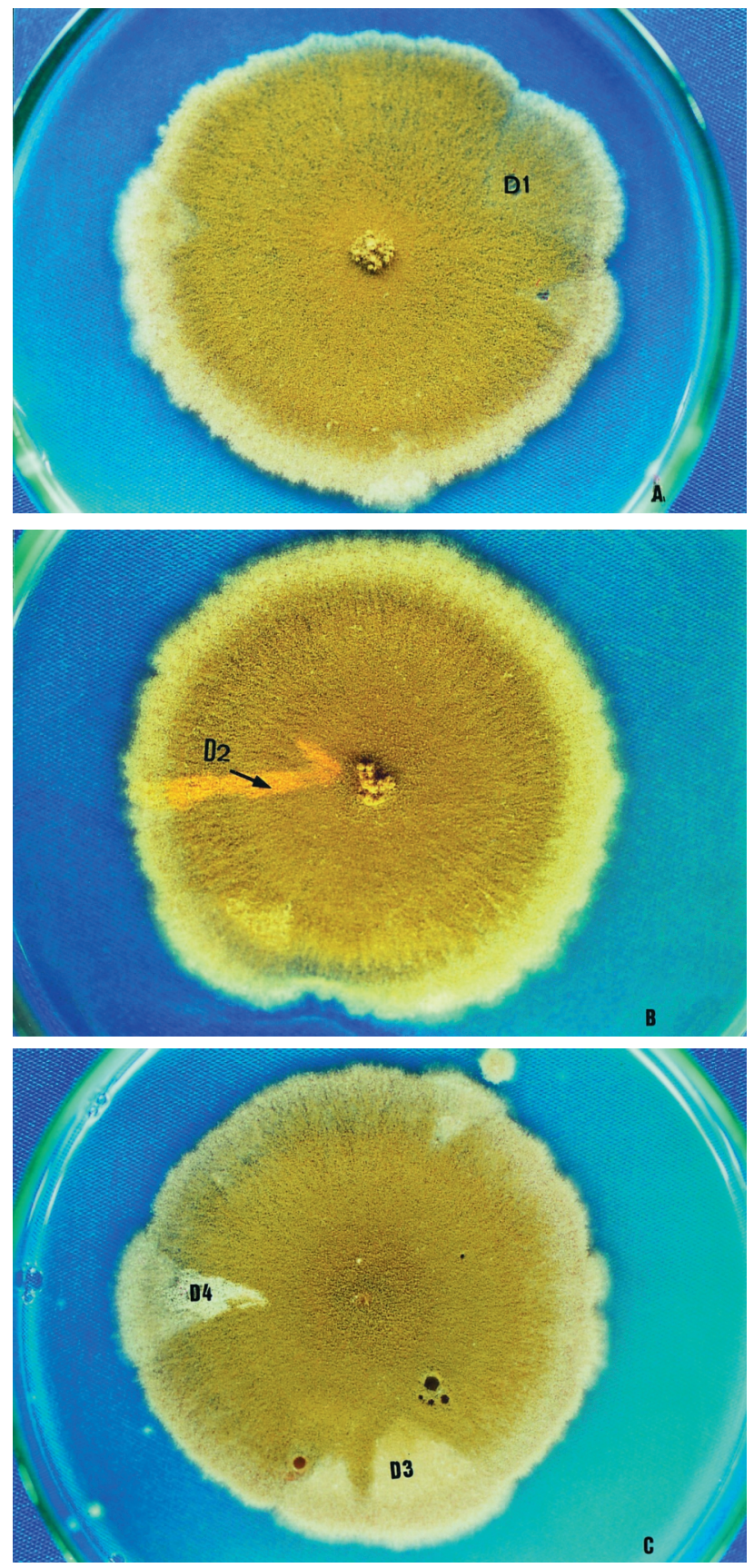

Figure 2 - Diploids D1, D2, D3 and D4 derived from the Z1//A757 diploid strain after treatment with $4.0 \times 10^{-3} \mu \mathrm{M}$ (D1) and $5.0 \times 10^{-3} \mu \mathrm{M}$ (D2-D4) of ethidium bromide in Minimal Medium.

with crinkled morphology were obtained among 63 haploid segregants, suggesting the presence of $\mathrm{Dp}(\mathrm{II}, \mathrm{I})$ in their genomes (Table 2, Figure 4).

The $5.0 \times 10^{-3} \mu \mathrm{M}$ EB concentration produced D2 and D3 diploid strains. D2 diploid showed HIs $>2.0$ only for ribo (chromosome I) and pyro (chromosome IV) markers, because it is a recombinant for the centromere-paba interval (chromosome I) and homozygous for the paba+, $y$ and $b i+$ genes (Table 2, Figure 5). On the other hand, the D3

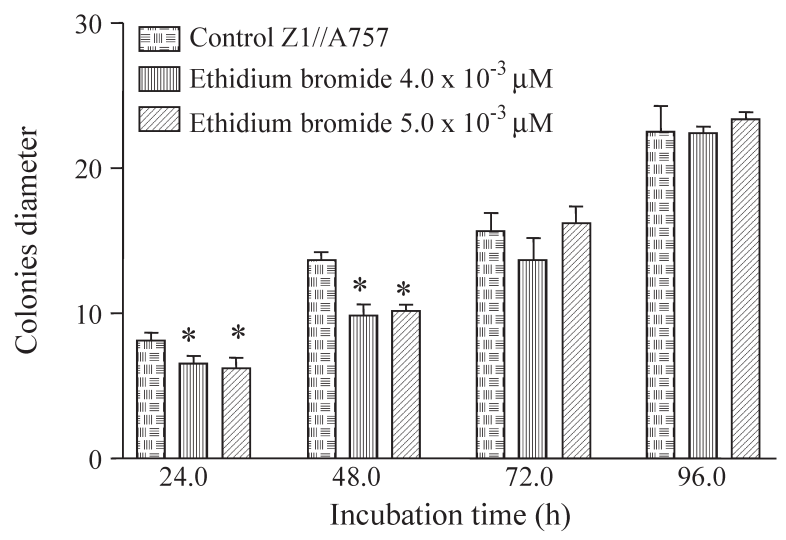

Figure 3 - Growth of diploid Z1//A757 in $\mathrm{CM}+4.0 \times 10^{-3} \mu \mathrm{M}$ and $\mathrm{CM}+$ $5.0 \times 10^{-3} \mu \mathrm{M}$ ethidium bromide. Control: Diploid growth in CM. $\left({ }^{*}\right)$ Significantly different from control, $\mathrm{p}<0.05$ (Student's $t$ test).

diploid strain showed HIs $>2.0$ for all chromosome I markers (ribo, paba and bi genes) (Table 2).

Taken together, the HI values for diploids D1-D3 demonstrate that $\mathrm{EB}$ induces mitotic recombination in $A$. nidulans diploid cells.

\section{Discussion}

A. nidulans duplication strains are very unstable at mitosis, with slow growth caused by genetic imbalance. They occasionally produce faster-growing sectors originated by the spontaneous loss of part or all of either duplicated segment (Nga and Roper, 1968, 1969).

The strains' mitotic instability may be enhanced by the incorporation of a $u v s$ mutation affecting DNA repair (Bur et al., 1982), since the spontaneous lesions that frequently occur in duplicated segments cannot be correctly repaired. It has also been shown that genome balance of heterozygous diploids for duplicated segments may be restored by deletion and mitotic crossing-over (Case and Roper, 1981).

The present study shows HIs $>2.0$ for chromosomes I and IV markers of Z1//A757 strain (Table 2, control). Results indicate that mitotic crossing-over in this diploid strain is probably caused by the spontaneous unrepaired lesions in its DNA. The intrinsic factors that induce mitotic instability in the Z1//A757 genome transform the diploid into a sensitive system for the detection of recombinagenesis induced by DNA molecule-breaking agents.

Moreover, D1-D3 diploids, obtained after treatment with EB, showed significantly greater $\mathrm{HI}$ values than those of the control in both concentrations (Table 2). Further, only treated diploid strains produced homozygous diploids for conidial colour: D2 and D4 produced yellow and white conidia, respectively (Figure 2). Results indicate that the intercalating agent is potentially capable of inducing mitotic crossing-over in A. nidulans diploid cells heterozygous for an extra translocated segment. 
Table 2 - Homozygotization Indexes (HI) of markers from the Z1 // A757 diploid strain exposed to $4.0 \times 10^{-3}$ and $5.0 \times 10^{-3} \mu \mathrm{M}$ of ethidium bromide.

\begin{tabular}{|c|c|c|c|c|c|c|c|c|}
\hline & \multicolumn{2}{|c|}{ Control $^{1}$} & \multicolumn{2}{|c|}{$\mathrm{D} 1\left(4.0 \times 10^{-3} \mu \mathrm{M}\right)$} & \multicolumn{2}{|c|}{$\mathrm{D} 2\left(5.0 \times 10^{-3} \mu \mathrm{M}\right)$} & \multicolumn{2}{|c|}{$\mathrm{D} 3\left(5.0 \times 10^{-3} \mu \mathrm{M}\right)$} \\
\hline & N. seg $^{2}$ & $\mathrm{HI}$ & N. seg & HI & N. seg & $\mathrm{HI}$ & N. seg & $\mathrm{HI}$ \\
\hline ribo+ & 54 & 3.85 & 55 & 6.87 & 52 & 4.33 & 45 & $9.00 *$ \\
\hline ribo- & 14 & & 8 & & 12 & & 5 & \\
\hline paba+ & 52 & 3.25 & 56 & $8.00 *$ & 64 & 0 & 44 & $7.33^{*}$ \\
\hline paba- & 16 & & 7 & & 0 & & 6 & \\
\hline$b i+$ & 53 & 3.53 & 56 & $8.00 *$ & 64 & 0 & 45 & $9.00^{*}$ \\
\hline$b i-$ & 15 & & 7 & & 0 & & 5 & \\
\hline pyro+ & 46 & 2.09 & 37 & 1.42 & 44 & 2.20 & 28 & 1.27 \\
\hline pyro- & 22 & & 26 & & 20 & & 22 & \\
\hline
\end{tabular}

$\left({ }^{1}\right)$ Control, HIs of markers from Z1//A757 diploid growing in the absence of EB; $\left({ }^{2}\right)$ N. seg., number of haploid mitotic segregants; HI, Homozygosity Index; $(*)$, Significantly different from control at $\mathrm{p}<0.05$ (Yates Correct Chi-square test, Statistic for Windows Program).

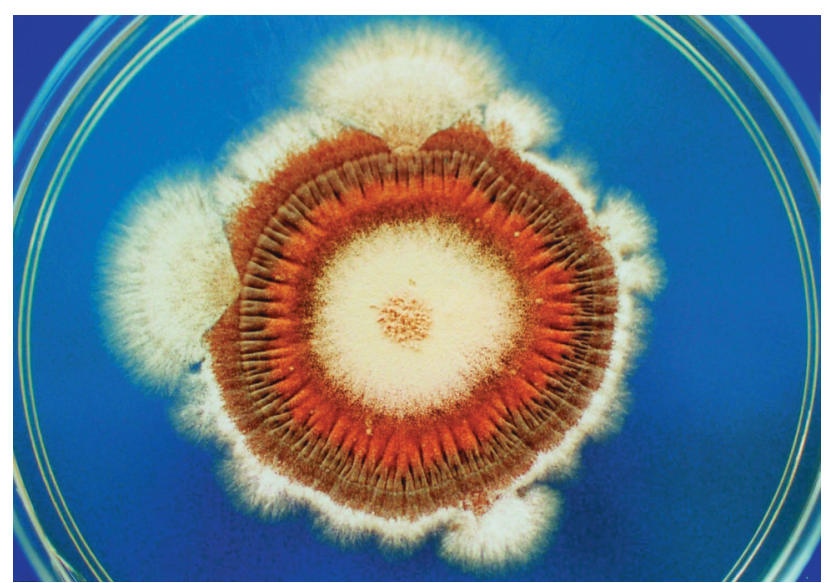

Figure 4 - Mitotic segregant with crinkled morphology produced by spontaneous haploidization of the D1 diploid strain.

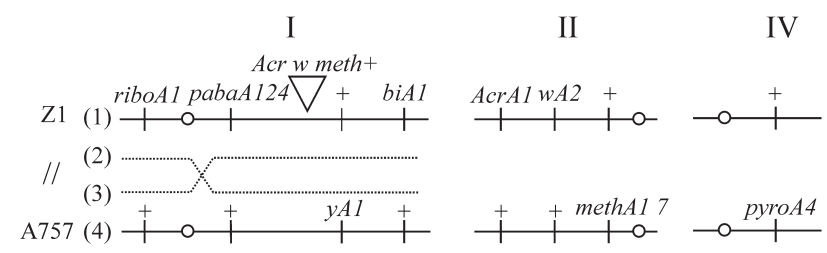

Figure 5 - Schematic representation of chromosome I of the D2 diploid. Segregation of the parental (4) and the recombinant (2) chromatids towards the same mitotic pole results in the paba+, y, bi+//paba+, y, bi+

EB is a compound that intercalates reversibly between pair bases of DNA molecule affecting many DNA functions including DNA and RNA synthesis and mitotic activity (Heinen et al., 1976). The DNA-binding drug was classified as an inhibitor of Topoisomerase II (Snyder and Arnone, 2002), DNA polymerase alpha, delta and epsilon from Novikoff hepatoma cells (Fox et al., 1996) and the unwinding DNA and ATPase activities of the plant nuclear helicase PDH45 (Pham and Tuteja, 2002).

Covalent attachment of EB to DNA in nanomolar concentrations enhances topoisomerase II-mediated sin- gle-and double-strand DNA cleavage. Therefore, the conversion of the reversible EB-DNA complex into an irreversible adduct causes the transformation of the drug into a catalytic topoisomerase II inhibitor (Snyder and Arnone, 2002; Marx et al., 1997).

Stable DNA double-strand breaks generated by EB, through inhibition of DNA topoisomerase II, may become templates for recombination events and possibly explain the recombinagenic effect of the drug demonstrated in the present work.

DNA topoisomerase II inhibitors are the most successful anticancer drugs used to treat human malignancies. They increase the number of enzyme-mediated DNA breaks by interfering with the DNA religation activity of the enzyme (Fortune and Osheroff, 2000). Nevertheless some of these antineoplastic agents have been associated with a distinct form of leukaemia characterised by chromosomal translocations as a treatment complication (Felix, 2001; Snyder, 2000).

Our research demonstrates that EB, a topoisomerase II inhibitor, induces mitotic crossing over in A. nidulans diploid cells heterozygous for duplicated segment Dp (II,I). Results suggest that DNA topoisomerase II inhibitors, such as EB, are potentially capable of inducing secondary malignancies mediated by mitotic crossing-over.

\section{Acknowledgments}

We would like to thank CAPES (Nucleus for Upgrading University Personnel), CNPq (National Council for Scientific and Technological Development) and the Foundation Araucária (Research Foundation of the State of Paraná) for their support. Thanks are also due to Ms. Sônia Aparecida de Carvalho and Mrs. Luzia de Souza Regazzi for their technical assistance.

\section{References}

Attia SM, Schmid TE, Badary OA, Hamada FM and Adler ID (2002) Molecular cytogenetic analysis in mouse sperm of 
chemically induced aneuploidy: studies with topoisomerase II inhibitors. Mutat Res 520:1-13.

Baptista F and Castro-Prado MAA (1997) Benlat-induced homozigosis from heterozygous diploids strain in Aspergillus nidulans. Cytologia 62:389-396.

Baptista F and Castro-Prado MAA (2001) A novel UV-sensitivity mutation induces nucleotide excision repair phenotype and shows epistatic relationships with UvsF and UvsB group in Aspergillus nidulans. J Microbiol 39:102-108.

Bur KW, Roper JÁ and Rilton J (1982) Modification of chromosome instability in Aspergillus nidulans. J Gen Microbiol 128:2899-2907.

Busso C, Chuichetta SJR, Baptista F and Castro-Prado MAA (2001) $u v s H / / u v s H$ diploid strain favors an efficient method to evaluate the recombinagenic effect of chemical and physical agents in Aspergillus nidulans (Ascomycetes). Acta Scientiarum 23:603-607.

Case BL and Roper JA (1981) Mitotic processes which restore genome balance in Aspergillus nidulans. J Gen Microbiol 124:9-16.

Castro-Prado MAA and Zucchi TMAD (1991) Meiotic segregation of a recessive gene (wA2) included in a Dp(II,I) of Aspergillus nidulans. Braz J Genet 14:249-260.

Chiuchetta SJR and Castro-Prado MAA (2002a) Recombinagenic effect of cryptolepine in $u v s H+/ / u v s H+$ and $u v s H / / u v s H$ diploid strains of Aspergillus nidulans. Folia Microbiol 47:516-520.

Chiuchetta SJR and Castro-Prado MAA (2002b) Vincristine induces somatic segregation, via mitotic crossing-over, in diploid cells of Aspergillus nidulans. Biol Res 35:5-12.

Faruqi SA, Miller RC and Noumoff JS (1994) Somatic pairing: An alternative for the development of cancer and other hereditary diseases. Cytol 59:439-444.

Felix C (2001) Leukemias related to treatment with DNA topoisomerase II inhibitors. Med Pediatr Oncol 36:525-535.

Fortune JM and Osheroff N (2000) Topoisomerase II as a target for anticancer drugs: when enzymes stop being nice. Prog Nucleic Acid Res Mol Biol 64:221-53.

Fox G, Popanda O, Edler L and Thielmann HW (1996) Preferential inhibition of DNA polymerases alpha, delta, and epsilon from Novikoff hepatoma cells by inhibitors of cell proliferation. J Cancer Res Clin Oncol 122:78-94.

Franzoni MGM, Gebara JS and Castro-Prado MAA (1997) On the recombinogenic activity of norfloxacin in a diploid strain of Aspergillus nidulans. Cytol 62:39-45.

Godard T, Deslandes E, Sichel F, Poul J-M and Gauduchon P (2002) Detection of topoisomerase inhibitor-induced DNA strand breaks and apoptosis by the alkaline comet assay. Mutat Res 520:47-56.

Heinen E, Bassleer R and Calberg CM (1976) Comparison of the effects of ethidium bromide and ethidium bromidedeoxyribonucleic acid complex in fibroblasts cultivated in vitro. Beitr Pathol 159:207-218.
Laird PW and Jaenisch R (1996) The role of DNA methylation in cancer genetics and epigenetics. Ann Rev Genet 30:441464.

Marx G, Zhou H, Grayes DE and Osheroff N (1997) Covalent attachment of ethidium to DNA results in anhanced topoisomerase II-mediated DNA cleavage. Biochem 36:1588415891.

Mo Y and Beck WT (1999) DNA damage signals induction of fas ligant in tumor cells. Mol Pharmacol 55:216-222.

Nga BH and Roper JA (1968) Quantitative intrachromosomal changes arising at mitosis in Aspergillus nidulans. Genet 58:193-209.

Nga BH and Roper JA (1969) A sister generating spontaneous intrachromosomal changes at mitosis in Aspergillus nidulans. Gen Res 14:63-70.

Nitiss JL and Beck WT (1996) Antitopoisomerase drug action and resistance. Eur J Cancer 32:958-966.

Pham XH and Tuteja N (2002) Potent inhibition of DNA unwinding and ATPase activities of pea DNA helicase 45 by DNAbinding agents. Biochem Biophys Res Commun 292:334339.

Pires LTA and Zucchi TMAD (1994). A new method to detect potencial genotoxic agents using mitotic crossing over in diploid strains of Aspergillus nidulans. Bras J Gen 17:371376.

Pontecorvo GJA, Rope LM, Hemmons KD, MacDonald AW and Bufton P (1953) The genetics of Aspergillus nidulans. Advan Genet 5:141-238.

Ramel C, Cederberg H, Magnusson J, Vogel E, Natarajan AT, Mullender LH, Nivard JM, Parry JM, Leyson A, Comendador MA, Sierra LM, Ferreiro JÁ and Consuegra S (1996) Somatic recombination, gene amplification and cancer. Mutat Res 353:85-107.

Roper A (1952) Production of heterozygous diploids in filamentous fungi. Experientia 8:14-15.

Snyder RD (2000) Use of catalytic topoisomerase II inhibitors to probe mechanisms of chemical-induced clastogenicity in Chinese hanster V79 cells. Environ Mol Mutagen 35:13-21.

Snyder RD and Arnone MR (2002) Putative identification of functional interactions between DNA intercalating agents and topoisomerase II using the V79 in vitro micronucleus assay. Mutat Res 503:21-35.

Tiburi M, Reguly ML, Schwartsmann G, Cunha KS, Lehmann M and Andrade HHR (2002) Comparative genotoxic effect of vincristine, vinblastine, and vinorelbine in somatic cells of Drosophila melanogaster. Mutat Res 519:141-149.

Van de Vate C and Jansen GJO (1978) Meiotic recombination in a duplication strain of Aspergillus nidulans. Gen Res 31:29-52.

Weinberg RA (1991) Tumor supressor genes. Science 254:1138-1146.

Zimmermann FK, Schwaier R and Laer U (1966) Mitotic recombination induced in Saccharomyces cerevisiae with nitrous acid, diethylsulfate and carcinogenic, alkylating nitrosamides. Z. Vererbungs 98:230-246.

Editor: Sérgio Olavo Pinto da Costa 